\title{
TÉCNICA DE RIEGO PARA INCREMENTAR LA EFICIENCIA DEL USO DE AGUA EN JITOMATE*
}

\section{IRRIGATION TECHNIQUE TO INCREASE THE EFICIENCY OF WATER USE IN TOMATO}

\author{
Anselmo López Ordaz ${ }^{1}$, Carlos Trejo López ${ }^{1}$, Carlos Ramírez Ayala $^{2}$, Cecilia Beatriz Peña Valdivia ${ }^{1}$, Leonardo Tijerina Chávez $^{2}$ \\ y José Alfredo Carrillo Salazar ${ }^{3}$

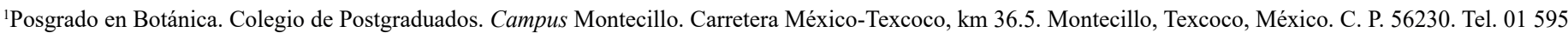

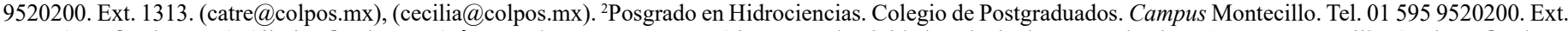

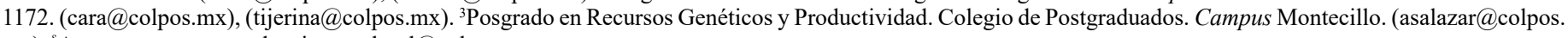 \\ $\mathrm{mx}) .{ }^{\S}$ Autor para correspondencia: anselmol@colpos.mx.
}

\section{RESUMEN}

El objetivo de esta investigación fue estudiar en condiciones de hidroponía e invernadero, el efecto de dos niveles de humedad aprovechable del sustrato en plantas de jitomate (Solanum lycopersicum L.), mediante la técnica de riego secado parcial de la raíz (SPR). Para ello se evaluaron variables fisiológicas (materia seca de hoja, tallo, raízy fruto, relaciones hídricas, intercambio de gases, rendimiento), calidad de fruto (firmeza, sólidos solubles totales, $\mathrm{pH}$ y conductividad eléctrica), y la eficiencia del uso de agua. El experimento se estableció en Lomas de San Esteban, Texcoco, Estado de México, en 2006. Las plantas crecieron en contenedores de volumen homogéneo, con tezontle, la raízse dividió en dos partes, y se aplicaron dos tratamientos de humedad aprovechable (HA) residual en el sustrato, testigo: $80 \% \leq \mathrm{HA} \leq 100 \%$ y $80 \% \leq \mathrm{HA} \leq 100 \%$ y SPR: $80 \% \leq \mathrm{HA} \leq$ $100 \%$ y $30 \% \leq \mathrm{HA} \leq 100 \%$. Estos tratamientos se iniciaron 28 días después del transplante y se mantuvieron hasta el final del experimento. Los resultados obtenidos indicaron que el tratamiento SPR mostró diferencias estadísticas significativas $(p \leq 0.05)$, respecto al testigo, en relación con la tasa de fijación de $\mathrm{CO}_{2}$ (SPR, 17.67 y testigo 9.23 $\mu \mathrm{mol} \mathrm{m} \mathrm{m}^{-2} \mathrm{~s}^{-1}$ ) a 86 días de haber iniciado los tratamientos (DDIT), volumen evapotranspirado por planta durante todo

\section{ABSTRACT}

The aim of this research was to study in hydroponics and greenhouse conditions the effect of two levels of usable moisture from the substrate in tomato plants (Solanum lycopersicum L.), by the irrigation technique of partial root drying (PRD). For that, physiological variables were evaluated (dry matter of leaf, stem, root and fruit, water relations, gas exchange, yield), fruit quality (firmness, total soluble solids, $\mathrm{pH}$ and electrical conductivity) and the efficiency of water use. The experiment was done in Lomas de San Esteban, Texcoco, Mexico State in 2006. Plants grew in homogeneous volume containers with tezontle, the root was divided in two parts and two available moisture (AM) treatments were applied residual in substrate, control: $80 \% \leq \mathrm{AM} \leq 100 \%$ and $80 \% \leq \mathrm{AM} \leq 100 \%$ and $\mathrm{PRD}: 80 \% \leq$ $\mathrm{AM} \leq 100 \%$ and $30 \% \leq \mathrm{AM} \leq 100 \%$. The treatments started 28 days after transplantation and continued until the end of the experiment. Results indicated that PRD treatment, showed statistically significant differences $(p \leq 0.05)$ than the control, in relation to $\mathrm{CO}_{2}$ fixation rate (PRD, 17.67 and control $9.23 \mu \mathrm{mol} \mathrm{m} \mathrm{m}^{-2} \mathrm{~s}^{-1}$ ) at 86 days of initiating the treatment (DAIT), evapotranspirated volume per plant throughout the experiment (PRD 186.7 L and control 229 L), fruit quality increased: firmness $25 \%$, total soluble

\footnotetext{
* Recibido: septiembre de 2010

Aceptado: julio de 2011
} 
el experimento (SPR 186.7 L y testigo 229 L), la calidad de fruto incrementó: firmeza $25 \%$, los sólidos solubles totales $13 \%$ y la conductividad eléctrica $13 \%$, respecto al testigo; y la eficiencia en el uso del agua (EUA) con base en la materia seca incrementó $29 \%$ y EUA instantánea fue de 57 , 61 y casi $100 \%$, respecto al testigo, a los 65,80 y 86 DDIT respectivamente, sin afectar el rendimiento (SPR $363.2 \mathrm{~g}$ $\mathrm{y}$ testigo $345.8 \mathrm{~g}$ ) y el potencial total del agua (SPR - $0.54 \mathrm{y}$ testigo - 0.57 ; SPR -0.46 y testigo $-0.55 \mathrm{MPa}$ ), a los 79 y 118 DDIT respectivamente.

Palabras claves: Solanum lycopersicum L., comunicación raíz-vástago, señales químicas.

\section{INTRODUCCIÓN}

Durante muchas décadas se reconoció que reducciones en el potencial de agua del vástago, como resultado de estrés hídrico, controlaban aspectos fundamentales de la fisiología de las plantas como crecimiento, diferenciación, intercambio de gases y cierre de estomas (Kramer, 1988). Sin embargo, después que Bates y Hall (1981) observaron en Vigna unguiculata inhibición del intercambio de gases, sin que existiera algún cambio en las relaciones hídricas, se ha demostrado en otras especies que el sistema radical es lo suficientemente sensible para detectar cambios en el contenido de humedad en el suelo, y enviar señales químicas al vástago para controlar crecimiento e intercambio de gases (Gowing et al., 1990; Zhang y Davies, 2009). Las respuestas fisiológicas que se han observado en condiciones de estrés, se han utilizado recientemente con la finalidad de incrementar el rendimiento de las plantas y la eficiencia del uso de agua. Loveys et al. (2000) desarrollaron una técnica que llamaron secado parcial de raíz (SPR). Esta técnica consiste en dividir longitudinalmente la raíz de una planta $\mathrm{y}$ crecer en contendores diferentes.

El contenido hídrico del sustrato de cada contenedor es controlado y alternado cada 14 días, para que en uno de ellos con menor contenido hídrico se estimule la producción de señales químicas en la raíz. During et al. (1996); Loveys et al. (2000) observaron en Vitis vinifera la reducción del crecimiento y conductancia estomática, pero ninguna alteración en las relaciones hídricas del vástago, tampoco reducción del rendimiento, esto dio como resultado un incremento de la eficiencia del uso de solids $13 \%$ and electrical conductivity $13 \%$, compared with control; efficiency in water use (EWU) based on dry matter increased by $29 \%$ and instantly EWU was 57, 61 and almost $100 \%$ respect to the control at 65,80 and 86 DAIT respectively, without affecting yield(PRD 363.2 g and control345.8 g) and total water potential (PRD - 0.54 and control -0.57 ; PRD - 0.46 and control $-0.55 \mathrm{MPa}$ ), at 79 and 118 DAIT respectively.

Key words: Solanum lycopersicum L., chemical signals, root-shoot communication.

\section{INTRODUCTION}

For many decades it was recognized that reductions in shoot water potential as a result of water stress, controlled fundamental aspects of plant physiology such as growth, differentiation, gas exchange and stomata closure (Kramer, 1988). However, after Bates and Hall (1981) observed in Vigna unguiculata the inhibition of gas exchange, without any change in water relations, in other species it has been shown that root system is sensitive enough to detect changes in soil's moisture content and to send chemical signals to the stem to control growth and gas exchange (Gowing et al., 1990; Zhang and Davies, 2009). Physiological responses that have been observed under stressful conditions have recently been used in order to increase plant yield and water use efficiency. Loveys et al. (2000) developed a technique called partial root drying (PRD), this technique consists in longitudinally split a plant's root and to grow them in different containers.

Water content of each container's substrate is controlled and alternated every 14 days, to induce in the one with less water content, the production of chemical signals in the root. During et al.(1996); Loveys et al. (2000), observed in Vitis vinifera a growth and stomatal conductance reduction, but there was no alteration in the shoot's water relations, neither yield reduction, this resulted in an increased water use efficiency. In other research with raspberry and tomato wherePRD technique was used, similar results were obtained to those of During et al.(1996); Loveys et al. (2000), related to physiological processes and water use efficiency (Davies et al., 2000; Stoll et al., 2002; Stikic et al., 2003).

Results found by these authors, suggest that PRD technique can be used in intensive production systems, to use the substrate's humidity control for taking advantage of 
agua. En otras investigaciones con frambuesa y jitomate en donde se utilizó la técnica SPR, se obtuvieron resultados similares con During et al. (1996); Loveys et al. (2000), referentes a los procesos fisiológicos y la eficiencia del uso de agua (Davies et al., 2000; Stoll et al., 2002; Stikic et al., 2003).

Los resultados que estos autores encontraron, sugieren que la técnica SPR puede ser utilizada en sistemas de producción intensiva, para que con el control de la humedad del sustrato, se tome ventaja de las señales químicas entre la raíz y el vástago. En estos mismos trabajos se señala que la intensidad y la duración del estrés determinan la magnitud de la respuesta fisiológica. Con base en lo anterior, la presente investigación tuvo como objetivo determinar en un sistema intensivo de producción de jitomate (hidroponía e invernadero), el efecto de diferentes niveles de humedad aprovechable residual en el sustrato con la técnica SPR en el crecimiento, relaciones hídricas, intercambio de gases, rendimiento, calidad de fruto y eficiencia del uso de agua.

\section{MATERIALES Y MÉTODOS}

El experimento se llevó a cabo en condiciones de hidroponía e invernadero en Lomas de San Esteban, Texcoco, Estado de México a $2250 \mathrm{msnm}, 19^{\circ} 29^{\prime}$ latitud norte y $98^{\circ} 54^{\prime}$ longitud oeste.

\section{Material vegetal}

Se utilizó semilla de jitomate (Solanum lycopersicum L.) híbrido "Gabriela", de crecimiento indeterminado. La siembra se realizó el 21 de mayo de 2006, mientras que el transplante fue el 1 de julio de 2006. Los tratamientos se iniciaron el 29 de julio de 2006 y terminaron el 24 de noviembre del mismo año. La siembra se realizó en charolas de polietileno con turba "Peat Moss" como sustrato. Después del trasplante y hasta un día antes que se iniciaron los tratamientos, las plantas se regaron con la solución nutritiva de Steiner(1984) a un potencial osmótico de $-0.036 \mathrm{MPa}$.

A partir del inicio de los tratamientos y hasta el final del experimento se completaron 118 días, todas las plantas se regaron con la solución nutritiva de Steiner (1984) con un potencial osmótico de -0.072 MPa. chemical signals between root and shoot. Those papers also indicate that intensity and duration of stress, determine the physiological response's magnitude. Based on that, this investigation aimed to determine in a tomato's production intensive system (hydroponics and greenhouse), the effect of different usable moisture residual levels in the substrate with the PRD technique, in growth, water relations, gas exchange, yield, fruit quality and efficiency of water use.

\section{MATERIALS AND METHODS}

The experiment was conducted in hydroponics and greenhouse conditions in Lomas de San Esteban, Texcoco, Mexico State at 2250 masl, $19^{\circ} 29^{\prime}$ north latitude and $98^{\circ}$ 54 'west longitude.

\section{Plant material}

We used tomato (Solanum lycopersicum L.) seeds "Gabriela" hybrid, of indeterminate growth. Sowing was made on May $21^{\text {th }} 2006$, while transplant was made in July $1^{\text {th }} 2006$. Treatments began on July $29^{\text {th }} 2006$ and ended on November $24^{\text {th }}$ of that year. Planting was done in polyethylene trays with "Peat Moss" turf as substrate. After transplantation, and even a day before the treatments began, plants were watered with Steiner's nutrient solution (1984) at an osmotic potential of $-0.036 \mathrm{MPa}$.

From the beginning of the treatments until the end of the experiment 118 days passed, all plants were watered with Steiner's nutrient solution (1984) with an osmotic potential of $-0.072 \mathrm{MPa}$.

\section{Transplantation}

Transplantation was made 40 days after sowing. When the seedlings showed the fifth true leaf, the root was split longitudinally into two equal parts with a knife from above the root collar to the tip. Subsequently, each root section of each plant was transplanted in two polyethylene bags of $40 * 40 \mathrm{~cm}$, one for each root section, joined in the center with tape. There were 5 plants $\mathrm{m}^{-2}$.

Each container had 14 L of porous volcanic rock (tezontle) with the following granulometry (particle weight) greater than $2 \mathrm{~mm}, 97.36 \% ; 0.84 \mathrm{~mm}, 2.1 \% ; 0.59 \mathrm{~mm}, 0.08 \% ; 0.42$ $\mathrm{mm}, 0.016 \%, 0.25 \mathrm{~mm}, 0.025 \%$ and less than $0.25 \mathrm{~mm}$, 


\section{Trasplante}

El trasplante se realizó 40 días después de la siembra. Cuando las plántulas presentaron la quinta hoja verdadera, la raíz se dividió longitudinalmente en dos partes iguales con una navaja, desde arriba del cuello de la raíz hasta su ápice. Posteriormente, cada sección de la raíz de cada planta se trasplantó en dos bolsas de polietileno de $40 * 40$ $\mathrm{cm}$, una para cada sección de la raíz, unidas en el centro con cinta adhesiva. Se establecieron 5 plantas $\mathrm{m}^{-2}$.

Cada contenedor tuvo $14 \mathrm{~L}$ de roca volcánica porosa (tezontle) con la siguiente granulometría (partículas en peso): mayor de $2 \mathrm{~mm}, 97.36 \% ; 0.84 \mathrm{~mm}, 2.1 \%$; $0.59 \mathrm{~mm}$, $0.08 \% ; 0.42 \mathrm{~mm}, 0.016 \%, 0.25 \mathrm{~mm}, 0.025 \%$ y menor 0.25 $\mathrm{mm}, 0.35 \%, \rho_{\mathrm{a}}=0.63 \mathrm{~g} \mathrm{~cm}^{-3}, \rho_{\mathrm{r}}=2.47 \mathrm{~g} \mathrm{~cm}^{-3} \mathrm{y}$ una retención de humedad de $1.9 \mathrm{~L}$ que corresponde a $18.4 \%$ de la porosidad total. Las plantas durante el crecimiento se mantuvieron hasta obtener 10 racimos como máximo y un solo tallo, al que se le eliminaron las yemas axilares cada siete días. Se podaron las hojas en estado de senescencia y las plantas se sostuvieron verticalmente con hilo rafia.

\section{Tratamientos}

Se establecieron dos tratamientos con diferente humedad aprovechable (HA) residual en el sustrato, testigo: $80 \leq$ $\mathrm{HA} \leq 100 \%$ y $80 \leq \mathrm{HA} \leq 100 \%$; SPR: $80 \leq \mathrm{HA} \leq 100 \%$ y $30 \leq \mathrm{HA} \leq 100 \%$. El tratamiento testigo se regó en ambos lados de la raíz hasta alcanzar la capacidad de retención de humedad del sustrato (CRHS=1.9 L), donde se permitió que se evapotranspirara $20 \%$ de la humedad aprovechable para entonces regar el sustrato hasta alcanzar nuevamente la CRHS (Figura 1 A). Para el tratamiento SPR, el lado húmedo fue tratado igual que en el tratamiento testigo; en cambio, en el lado seco se permitió que se evapotranspirara hasta $70 \%$ de la humedad aprovechable, antes de regresar a CRHS (Figura $1 \mathrm{~B}$ ).

El procedimiento de riego se aplicó sin alternar el lado húmedo y con estrés hídrico durante todo el tiempo que se llevó a cabo el experimento. El 100\% de humedad aprovechable correspondió a la máxima capacidad de retención de humedad aprovechable disponible, equivalente a una retención de agua de 1.9 L. Este valor se obtuvo con cuatro macetas de $14 \mathrm{~L}$ de sustrato, con características físicas mencionadas anteriormente, se aplicó un volumen conocido de agua hasta punto de saturación y se mantuvo durante $24 \mathrm{~h}$, posteriormente
$0.35 \%, \rho_{\mathrm{a}}=0.63 \mathrm{~g} \mathrm{~cm}^{-3}, \rho_{\mathrm{r}}=2.47 \mathrm{~g} \mathrm{~cm}^{-3}$ and a moisture retention of $1.9 \mathrm{~L}$, corresponding to $18.4 \%$ of total porosity. During growth, plants were maintained until a maximum of 10 clusters and a single stem, which axillary buds were removed every seven days. Leaves were pruned in senescence state and plants were held vertically with raffia.

\section{Treatments}

There were two treatments with different available moisture (AM) residual in substrate, control: $80 \leq \mathrm{AM} \leq 100 \%$ and $80 \leq$ $\mathrm{AM} \leq 100 \%$; PRD: $80 \leq \mathrm{AM} \leq 100 \%$ and $30 \leq \mathrm{AM} \leq 100 \%$. Control treatment was irrigated on both root sides to reach the substrate's moisture retention capacity $(\mathrm{SMRC}=1.9 \mathrm{~L})$, where were allowed evapotranspiration of $20 \%$ of usable moisture and then substrate was watered to reach again the SMRC (Figure 1 A). For PRD treatment, the wet side was treated the same as the control treatment, whereas on the dry side it was allowed an evapotranspiration up to $70 \%$ of usable moisture, before returning to SMRC (Figure 1 B).

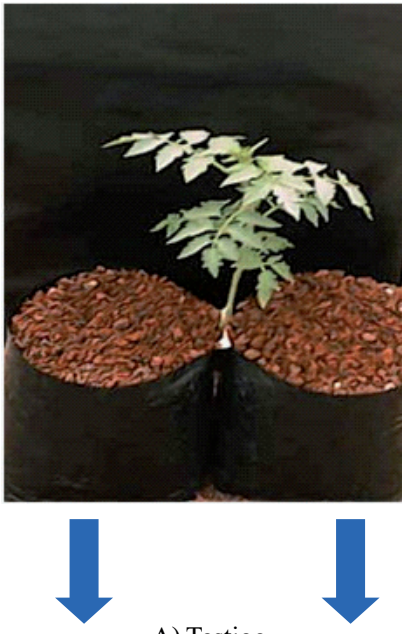

A) Testigo

$80 \% \leq \mathrm{HA} \leq 100 \% \quad 80 \% \mathrm{HA} \leq 100 \%$ Lado húmedo Lado húmedo

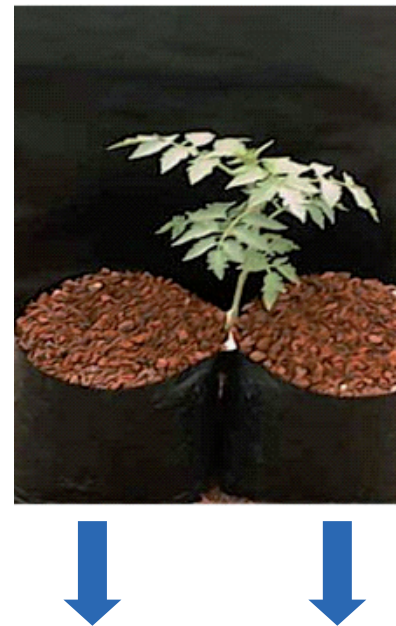

B) SPR

$80 \% \leq \mathrm{HA} \leq 100 \% \quad 30 \% \leq \mathrm{HA} \leq 100 \%$ Lado húmedo Lado seco
Figura 1. Humedad aprovechable residual en el sustrato, para el desarrollo de plantas de jitomate con raíz dividida. A) testigo, ambos lados de la raíz a humedad aprovechable; y B) secado parcial de la raíz(SPR), con un lado a humedad aprovechable y otro disminuyó hasta $30 \%$.

Figure 1. Available residual moisture in the substrate for the development of tomato plants with split root. A) control, both sides of the root to available moisture; and $\mathrm{B}$ ) partial root drying (PRD) with a side to available moisture and other decreased to $30 \%$. 
se dejó drenar y por diferencia se obtuvo $1.9 \mathrm{~L}$, que corresponde a la máxima capacidad de retención de humedad aprovechable disponible.

\section{Evapotranspiración}

El nivel de humedad se controló diariamente mediante la evapotranspiración medida dentro del invernadero y con referencia a las macetas testigo de cada tratamiento. Éstas tuvieron un volumen de sustrato $(14 \mathrm{~L})$ y una capacidad de retención de humedad conocida (1.9 L). Para lograr dicho control, a las 7:00 h y 13:00 h se aplicaron volúmenes de solución nutritiva conocidos y se dejó que drenara durante una hora. Se midió la solución nutritiva que drenó de la maceta testigo y por diferencia entre la solución nutritiva aplicada en el sustrato de cada maceta testigo y el volumen drenado, se obtuvo el volumen evapotranspirado. Este volumen se aplicóa todas las plantas de los tratamientos correspondientes (Figura 2). Cabe mencionar que se aplicó el mismo volumen de solución nutritiva en ambos tratamientos con base en el tratamiento testigo: $80 \% \leq \mathrm{HA} \leq 100 \%$ y $80 \% \leq \mathrm{HA} \leq 100 \%$ en ambos lados de la raíz, durante los 28 días de adaptación.

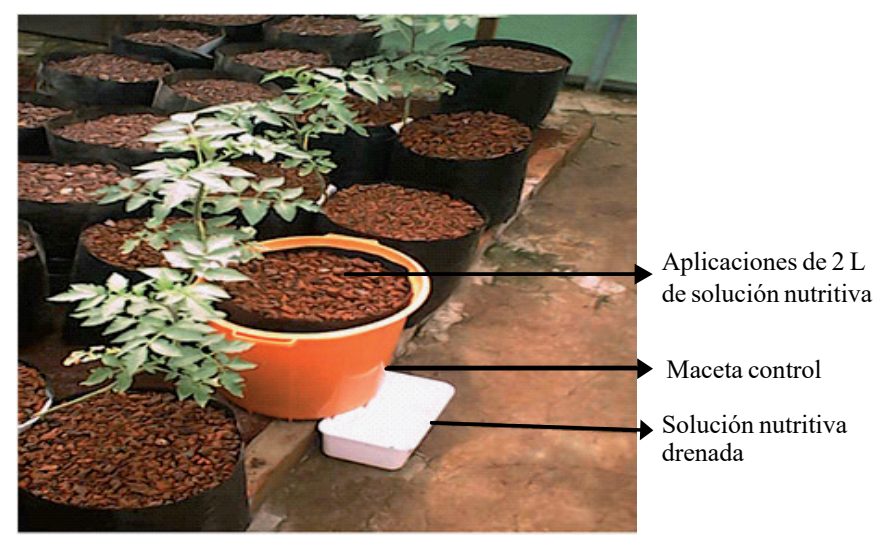

Figura 2. Evapotranspiración diaria medida con base a la maceta testigo en invernadero de plantas de jitomate con raíz dividida y secado parcial de raíz en condiciones de hidroponía.

Figure 2. Daily evapotranspiration measured using control pot in greenhouse of tomato plants with split root and partial root drying in hydroponic conditions.

\section{Diseño experimental y análisis estadístico}

Se utilizó el diseño experimental de bloques completos al azar con dos niveles de humedad aprovechable residual: testigo $(80 \% \leq \mathrm{HA} \leq 100 \%$ y $80 \% \leq \mathrm{HA} \leq 100 \%)$ y $\mathrm{SPR}(80 \% \leq$
Irrigation procedure was applied without switching the wet side and with water stress during the experiment. $100 \%$ of available moisture corresponded to the maximum holding capacity of feasible available moisture, equivalent to a water retention of 1.9L. This value was obtained with four pots of 14 Lof substrate, with physical characteristics mentioned above, we applied a known water volume to saturation point and it was maintained for $24 \mathrm{~h}$, then it drained and by difference it was obtained an amount of $1.9 \mathrm{~L}$, corresponding to the maximum retention capacity of feasible available moisture.

\section{Evapotranspiration}

Moisture level was monitored daily by measuring evapotranspiration in the greenhouse and with reference to control pots of each treatment. They had a substrate volume (14 L) and a known moisture-retention capacity (1.9 L). To achieve this control, at 7:00 and 13:00 h known volumes of nutrient solution were applied and they were allowed to drain for an hour. It was measured the nutrient solution drained from control pot and evapotranspiration volume was obtained by the difference between the nutrient solution applied in the substrate of each control pot and the drained volume. This volume was applied to all plants of each treatment (Figure 2). It is noteworthy that the same volume of nutrient solution was applied in both treatments based on the control treatment: $80 \% \leq \mathrm{AM} \leq 100 \%$ and $80 \% \leq \mathrm{AM} \leq$ $100 \%$ on both root sides, within the 28 adaptation days.

\section{Experimental design and statistical analysis}

The experimental design of randomized blocks was used, with two available residual moisture levels: control $(80 \% \leq$ $\mathrm{AM} \leq 100 \%$ and $80 \% \leq \mathrm{AM} \leq 100 \%)$ and $\mathrm{PRD}(80 \% \leq \mathrm{AM} \leq$ $100 \%$ y $30 \% \leq \mathrm{AM} \leq 100 \%$ ), with six repetitions. Each experimental unit consisted of 12 plants with a total of 144 plants in the experiment.

Statistical analysis and data graphing were performed using the Sigma Plot program of Jandel Scientific (2001, version 7.1) to $p \leq 0.05$.

\section{Study variables}

\section{Dry matter of leaf, stem, root and fruit}

There were four destructive samplings every 30 days. Plants were cut at the base and three plants per treatment were dissected in different organs (root, leaf, stem and fruit). The 
$\mathrm{HA} \leq 100 \%$ y $30 \% \leq \mathrm{HA} \leq 100 \%$ ) con seis repeticiones. Cada unidad experimental consistió de 12 plantas, con un total de 144 plantas en el experimento.

El análisis estadístico y la representación gráfica de los datos se realizaron con el programa Sigma Plot de Jandel Scientific (2001, versión 7.1) a una $(p \leq 0.05)$.

\section{Variables de estudio}

\section{Materia seca de hoja, tallo, raíz y fruto}

Se hicieron cuatro muestreos destructivos cada 30 días. Las plantas se cortaron en la base y se disectaron tres plantas por tratamiento en sus diferentes órganos (raíz, hoja, tallo y fruto). Se determinó el peso de la materia seca de los diferentes órganos de las plantas. Dichos órganos se secaron en una estufa a $70^{\circ} \mathrm{C}$ hasta peso constante, y se pesaron en una balanza electrónica (Sartorius) con precisión de $0.1 \mathrm{~g}$.

\section{Relaciones hídricas}

Para la determinación de las relaciones hídricas (potencial de agua total, potencial osmótico y potencial de presión) los foliolos se desprendieron de la planta a los 79 y 118 días después de iniciados los tratamientos. El potencial de agua total $\left(\Psi_{\mathrm{A}}\right)$ se determinó en un foliolo del segundo par, correspondientes a hojas completamente expandidas, ubicadas abajo del quinto y noveno racimo, respectivamente, con una bomba de presión tipo Scholander (Soil Moisture, Santa Bárbara, California, USA). Para esto, el foliolo se separó de la planta e inmediatamente se introdujo en la cámara de medición de presión, dejando un segmento del pecíolo fuera.

Posteriormente, se aplicó lentamente presión neumática, generada con gas nitrógeno, hasta que se observó en el corte del pecíolo fuera de la cámara, la primera gota de savia de los haces vasculares, indicando el balance de presión. En ese momento se tomó la lectura del manómetro y se expresó en $\mathrm{MPa}$. Una vez determinado el $\Psi_{\mathrm{A}}$, el foliolo se envolvió en papel aluminio y se almacenó en nitrógeno líquido para la determinación, en el laboratorio, del potencial osmótico $\left(\Psi_{\mathrm{s}}\right)$.

Los foliolos se sacaron del tanque con nitrógeno líquido y se descongelaron. Despuésse colocaronenjeringas hipodérmicas y con la aplicación de presión manual al émbolo de la jeringa se extrajo el contenido celular. Se tomaron $10 \mu \mathrm{Ldel}$ contenido celular, y se incubaron directamente en un osmómetro de presión de vapor (VAPRO/WESCOR 5520). Las lecturas dry matter weight of different plant organs was determined. These organs were dried in an oven at $70{ }^{\circ} \mathrm{C}$ to constant weight and weighed on an electronic balance (Sartorius) with an accuracy of $0.1 \mathrm{~g}$.

\section{Water relations}

In order to determine water relations (total water potential, osmotic potential and pressure potential), leaflets were detached from the plant at 79 and 118 days after the onset of the treatment. Total water potential $\left(\Psi_{\mathrm{A}}\right)$ was determined in a leaflet of the second pair, corresponding to fully expanded leaves, located below the fifth and ninth cluster, respectively, with a Scholander type pressure bomb (Soil Moisture, Santa Barbara, California, USA). For this, leaflet was separated from the plant and was immediately introduced into the measuring pressure chamber, leaving out a petiole's segment.

Subsequently, a nitrogen gas generated air pressure was slowly applied, until in the petiole's cutting outside of the chamber was observed the first sap drop from the vascular bundles, indicating pressure balance. At that time the manometer reading was taken and it was expressed in MPa. Having determined the $\Psi_{\mathrm{A}}$, the leaflet was wrapped in aluminum foil and stored in liquid nitrogen for laboratory determination of osmotic potential $\left(\Psi_{\mathrm{s}}\right)$.

Leaflets were removed from liquid nitrogen tank and thawed. Then placed in syringes and with manual application of pressure to the syringe plunger it was removed the cell content. We took $10 \mu \mathrm{L}$ of cell content and incubated directly on a vapor pressure osmometer (VAPRO/WESCOR 5520). Readings were obtained in mmol kg-1 and converted to $\mathrm{MPa}$ using the equation: $\Psi_{\mathrm{s}}=-\mathrm{CRT}$, where: $\mathrm{C}=$ solution concentration (solute moles per $\mathrm{kg}$ of water), $\mathrm{R}=0.00831$ $\mathrm{kg} \mathrm{MPa} \mathrm{mol}^{-1}{ }^{\circ} \mathrm{K}^{-1}$ (general gas constant), $\mathrm{T}=$ absolute temperature $\left({ }^{\circ} \mathrm{K}={ }^{\circ} \mathrm{C}+273\right)$. Pressure potential $\left(\Psi_{\mathrm{p}}\right)$ was obtained by difference in the values of total water potential and osmotic potential, according to the general equation: $\Psi_{\mathrm{A}}=\Psi_{\mathrm{s}}+\Psi_{\mathrm{p}}$.

\section{Gas exchange}

The carbon fixation rate $\left(\mu \mathrm{mol} \mathrm{m} \mathrm{m}^{-2} \mathrm{~s}^{-1}\right)$, stomatal conductance $\left(\mathrm{mmol} \mathrm{m}^{-2} \mathrm{~s}^{-1}\right)$ and transpiration $(\mathrm{mmol}$ $\mathrm{m}^{-2} \mathrm{~s}^{-1}$ ) were determined at 23,36, 65, 80, 86 and 93 days after initiating treatments (DAIT). These variables 
se obtuvieron en mmoles $\mathrm{kg}^{-1}$ y se convirtieron a MPa con la ecuación: $\Psi_{\mathrm{s}}=$-CRT; donde: $\mathrm{C}=$ concentración de la solución (moles de soluto por $\mathrm{kg}$ de agua); $\mathrm{R}=0.00831 \mathrm{~kg} \mathrm{MPa} \mathrm{mol}^{-1}$ ${ }^{\circ} \mathrm{K}^{-1}$ (constante general de los gases); $\mathrm{T}=$ temperatura absoluta $\left({ }^{\circ} \mathrm{K}={ }^{\circ} \mathrm{C}+273\right)$. El potencial de presión $\left(\Psi_{\mathrm{p}}\right)$ se obtuvo por diferencia de los valores de potencial de agua total y osmótico, de acuerdo con la ecuación general: $\Psi_{\mathrm{A}}=\Psi_{\mathrm{s}}+\Psi_{\mathrm{p}}$.

\section{Intercambio de gases}

La tasa de fijación de bióxido de carbono $\left(\mu \mathrm{mol} \mathrm{m} \mathrm{m}^{-2} \mathrm{~s}^{-1}\right)$, conductancia estomática $\left(\mathrm{mmol} \mathrm{m} \mathrm{m}^{-2} \mathrm{~s}^{-1}\right)$ y transpiración $\left(\mathrm{mmol} \mathrm{m}^{-2} \mathrm{~s}^{-1}\right)$, se determinaron a 23, 36, 65, 80, 86 y 93 días después de haber iniciado los tratamientos (DDIT). Estas variables se midieron en la hoja más joven completamente expandida, en las horas de mayor radiación, con un sistema de análisis de gases portátil, abierto, en el espectro infrarrojo (CIRA-1, PP-SYSTEMS).

\section{Rendimiento}

Se cosecharon solamente los frutos de los primeros diez racimos cuando alcanzaron el sexto estado de madurez. Se determinó la materia fresca y seca $\left(70{ }^{\circ} \mathrm{C}\right.$ hasta peso constante) por fruto y con esta información se determinó el rendimiento por planta.

\section{Calidad de fruto}

Al momento de la cosecha, se seleccionaron cinco frutos por tratamiento y se determinó su firmeza, contenido de sólidos solubles totales $\left({ }^{\circ} \mathrm{Bx}\right), \mathrm{pH}$ y conductividad eléctrica. La firmeza del fruto se determinó con un texturómetro (Universal Fuerza Five) con escala de 0.1 hasta $0.32 \%$ de fuerza y un puntal cónico de $0.8 \mathrm{~mm}$ de diámetro; el resultado fue expresado en kilogramos fuerza ( $\mathrm{kg} \mathrm{f}$ ). Los sólidos solubles totales $\left({ }^{\circ} \mathrm{Bx}\right)$, se determinaron con un refractómetro digital, marca ATAGO, con escala de 0 hasta $32 \%$, con la metodología propuesta por laAOAC(1990). Se trituraron 10 g de pulpa con $50 \mathrm{~mL}$ de agua destilada, se filtró para eliminar los restos de tejido vegetal, y en una alícuota de $20 \mathrm{~mL}$ se determinó el $\mathrm{pH}$ con un potenciómetro y la conductividad eléctrica con un conductímetro portátil.

\section{Eficiencia en el uso del agua (EUA)}

Se procedió a calcular la EUA en dos formas: a) con base en la producción de materia fresca y seca de fruto y el agua evapotranspirada de acuerdo con la siguiente igualdad: were measured on fully expanded youngest leaf at peak radiation hours with a portable gas analysis system, open, in infrared spectrum (CIRA-1, PP-SYSTEMS).

\section{Yield}

At the sixth stage of maturity, only the fruits of the first ten clusters were harvested. The fresh and dry matter was determined $\left(70^{\circ} \mathrm{C}\right.$ to constant weight $)$ per fruit and with this information the yield per plant was determined.

\section{Fruit quality}

At the time of harvest, we selected five fruits per treatment and its firmness was determined, total soluble solids content $\left({ }^{\circ} \mathrm{Bx}\right), \mathrm{pH}$ and electrical conductivity. Fruit firmness was determined with a texture analyzer (Universal Force Five) scaled from 0.1 to $0.32 \%$ of strength and a conical strut with $0.8 \mathrm{~mm}$ of diameter, the result was expressed in kilograms force $(\mathrm{kg} f)$. Total soluble solids $\left({ }^{\circ} \mathrm{Bx}\right)$ were determined with a digital refractometer, ATAGO trade mark, with a scale of 0 to $32 \%$, with methodology proposed by AOAC (1990). $10 \mathrm{~g}$ of pulp were crushed with $50 \mathrm{~mL}$ of distilled water, filtered to remove traces of plant tissue, in a $20 \mathrm{~mL}$ aliquot it was measured $\mathrm{pH}$ with a potentiometer and the electrical conductivity with a portable conductometer.

\section{Efficiency in water use (EWU)}

EWU was calculated in two ways: a) based on the production of fresh and dried fruit matter and evapotranspirated water according to the following equation: EWU = grams of fresh or dried fruit matter/gram of evapotranspirated water; and b) with the quotient of the carbon fixation rate $\left(\mathrm{CO}_{2}\right)$ respect to transpiration (instant efficiency in water use in the leaf).

\section{RESULTS AND DISCUSSION}

\section{Dry matter of fruit, stem, leaf and root}

Production of dry matter of fruit and root, in function of time for both treatments (Figure 3A and 3D), showed no statistically significant differences. These results are similar to those reported by Davies et al. (2000), in relation to dry matter of fruit and root of tomato plants with PRD. In contrast, other researches like Stikic et al. (2003), even though they did not found statistically significant differences 
$\mathrm{EUA}=$ gramos de materia fresca o seca de fruto/gramo de agua evapotranspirada; y b) con el cociente de la tasa de fijación de bióxido de carbono $\left(\mathrm{CO}_{2}\right)$ con respecto a la transpiración (eficiencia en el uso del agua instantánea en la hoja).

\section{RESULTADOS Y DISCUSIÓN}

\section{Materia seca de fruto, tallo, hoja y raíz}

La producción de la materia seca de fruto y raíz en función del tiempo en ambos tratamientos (Figura 3A y 3D), no mostró diferencias estadísticas significativas. Éstos resultados son similares a los reportados por Davies et al. (2000) en relación con la materia seca de fruto y raíz de plantas de jitomate con el SPR. En contraste, otros investigadores, como Stikic et al. (2003), aunque no encontraron diferencias estadísticas significativas en la relación materia seca de fruto por planta, sí la encontraron en la relación materia seca de raíz por planta. De acuerdo con los datos obtenidos, los cambios en la materia seca de tallo y hoja en ambos tratamientos fueron similares (Figura 3B y 3C).

Sin embargo, a 60 y 90 días de haber iniciado los tratamientos (DDIT) respectivamente, el tratamiento SPR disminuyó significativamente con relación al testigo. En otros estudios con plantas de jitomate, en los que se utilizó la condición SPR, se obtuvieron resultados semejantes a los del presente estudio con relación a la materia seca de tallos y hojas (Davies et al., 2000; Stikic et al., 2003). En contraste, los resultados del presente estudio no coinciden con lo señalado por Dorji et al. (2005), quienes indicaron que el tratamiento SPR en plantas de chile no afectó estadísticamente la materia seca de la raíz, hojas, tallo y frutos.

\section{Relaciones hídricas e intercambio de gases}

El potencial de agua total, potencial osmótico y potencial de presión (Figura 4), a 79 y 118 DDIT fueron iguales entre los dos tratamientos. Estos resultados son semejantes a los reportados por Loveys et al. (2000); Stikic et al. (2003), quienes no encontraron diferencias en el potencial hídrico de plantas de vid y jitomate, respectivamente. Los resultados pueden ser tomados como evidencia que el tratamiento SPR activa el sistema de señales químicas en la raíz y como consecuencia mantiene las relaciones hídricas. in relation of fruit dry matter per plant, they did found it in relation of root dry matter per plant. According to data, changes in dry matter of stem and leaf in both treatments were similar (Figure 3B and 3C).

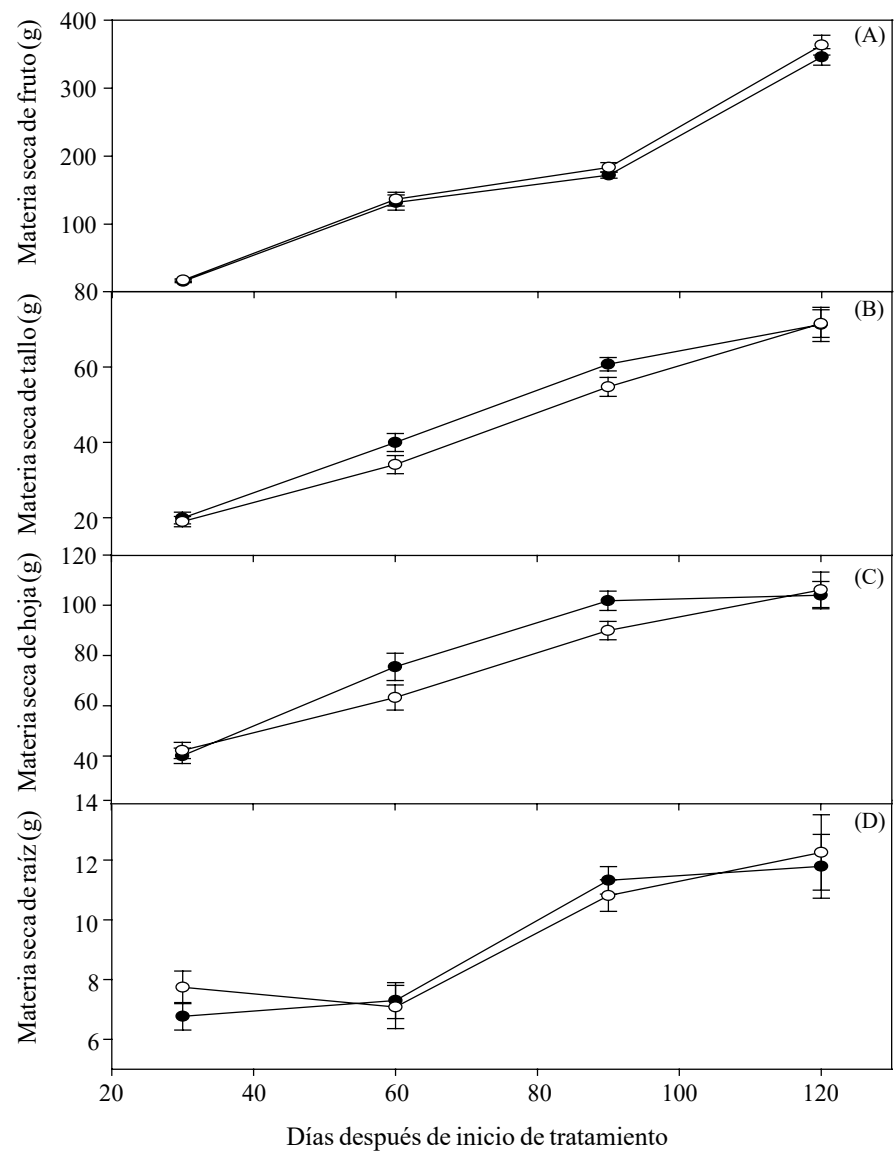

Figura 3. Plantas de jitomate después de iniciado los tratamientos hasta el final del experimento. A) Materia seca de fruto; B) tallo; C) hoja; y D) raíz. $\bullet=$ testigo; $\mathrm{O}=\mathrm{SPR}$. Cada punto representa el promedio de seis repeticiones \pm error estándar.

Figure 3. Tomato plants after treatment beginning until the end of the experiment. A) dry matter of fruit, B) stem; C) leaf; and D) root. $\bullet=$ control; $\circ=$ PRD. Each point represents the average of six replicates \pm standard error

However, at 60 and 90 DAIT respectively, PRD treatment decreased significantly in relation to the control. In other researches with tomato plants in which PRD condition was used, results were similar to those of the present paper in relation to dry matter of stems and leaves (Davies et al. 2000; Stikic et al., 2003). In contrast, results of this paper do not concord with those indicated by Dorji et al. (2005), who indicated that PRD treatment in chillipepper plants SPR did not statistically affect dry matter of roots, leaves, stems and fruits. 


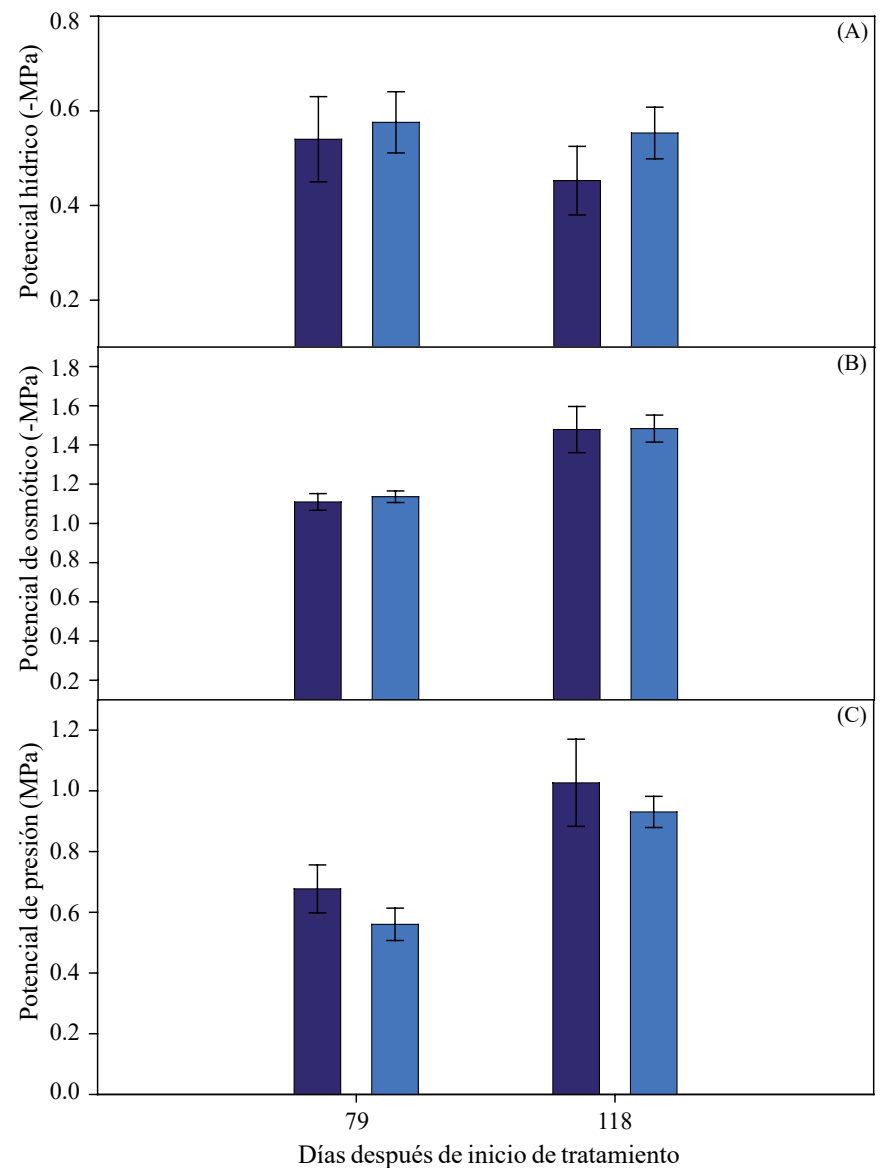

Figura 4. A) Potencial hídrico (-MPa); B) Potencial osmótico (-MPa); y C) Potencial de presión (MPa) en hojas de plantas de jitomate con raíz dividida en hidroponía e invernadero. Testigo $=$ barras obscuras; y SPR=barras claras. Cada punto representa el promedio de seis repeticiones \pm error estándar.

Figure 4. A) Water potential (-MPa), B) osmotic potential (-MPa), and C) pressure potential (MPa) in leaves of tomato plants with split root in hydroponics and greenhouse. Control = dark bars, and PRD = light bars. Each point represents the average of six replicates \pm standard error.

Bates y Hall (1981); During et al. (1996); Loveys et al. (2000), observaron la inhibición del intercambio de gases, sin presentarse ningún cambio en el potencial hídrico, en experimentos con sistema de raízdivididay SPR. Laactivación de señales químicas en la raíz de las plantas de jitomate con el SPR, también está soportada por los resultados de intercambio de gases obtenidos en esta investigación. Las variables se determinaron a 23, 36, 65, 80, 86 y 93 DDIT (Figura 5). La tasa de fijación de $\mathrm{CO}_{2}$ (Figura $5 \mathrm{~A}$ ) de ambos tratamientos incrementó gradualmente, hasta alcanzar al testigo y SPR un máximo de 9.2 y $17.7 \mu \mathrm{molm}^{-2} \mathrm{~s}^{-1}$ respectivamente, a 86DDIT.

\section{Water relations and gas exchange}

Total water potential, osmotic potential and pressure potential (Figure 4), at 79 and 118 DAIT were identical between both treatments. These results are similar to those reported by Loveys et al. (2000); Stikic et al. (2003), who did not found differences in water potential of grapevines and tomato plants, respectively. Results can be taken as evidence that PRD treatment actives the chemical signals system in the root and consequently keeps water relations.

Other researchers such as Bates and Hall (1981); During et al. (1996); Loveys et al. (2000), observed the inhibition of gas exchange without any change in water potential, in experiments with split root system and PRD, respectively. The activation of chemical signals in the root of tomato plants using PRD is also supported by gas exchange results obtained in this investigation. These variables were measured at 23, 36, 65, 80, 86 and 93 DAIT (Figure 5A, 5B and $5 \mathrm{C}$ ). $\mathrm{CO}_{2}$ fixation rate (Figure $5 \mathrm{~A}$ ) of both treatments gradually increased, until reaching in control and PRD a maximum of 9.2 and $17.7 \mu \mathrm{mol} \mathrm{m}^{-2} \mathrm{~s}^{-1}$ respectively, at 86 DAIT.

However, at 93 DAIT it was drastically reduced to 7.5 and $6.07 \mu \mathrm{mol} \mathrm{m}^{-2} \mathrm{~s}^{-1}$, respectively. It is obvious that $\mathrm{CO}_{2}$ fixation rate due to PRD treatment was 52, 47 and $91 \%$ greater than the control at 65,80 and 86 DAIT. Control's stomatal conductance and PRD was drastically reduced from 691 and 605 to 206 and $189 \mathrm{mmol} \mathrm{m}^{-2} \mathrm{~s}^{-1}$, respectively (Figure 5B). AT 65, 80 and 86 DAIT, PRD treatment significantly reduced stomatal conductance at 18,25 and 16\% compared with control. In contrast, in transpiration, PRD treatment had no effect (Figure 5C). While stomatal conductance and transpiration decreased over time and $\mathrm{CO}_{2}$ fixation rate tended to increase. During (2008), states that $\mathrm{CO}_{2}$ fixation rate has a nonlinear relation with stomatal conductance and this caused an instantaneous increase in the EWU.

In general, this physiological response has been attributed to the stomata partial closure, generated by chemical signals originated in the root under water stress (During et al. 1996; Davies et al., 2000; Loveys et al.2000). However, in a research with a similar treatment in the same species, it was not found a significant effect on $\mathrm{CO}_{2}$ fixation rate and transpiration (Stikic et al., 2003). General physiological response appears to be similar between researches conducted by various groups when the PRD condition has been evaluated. However, some notable differences have 


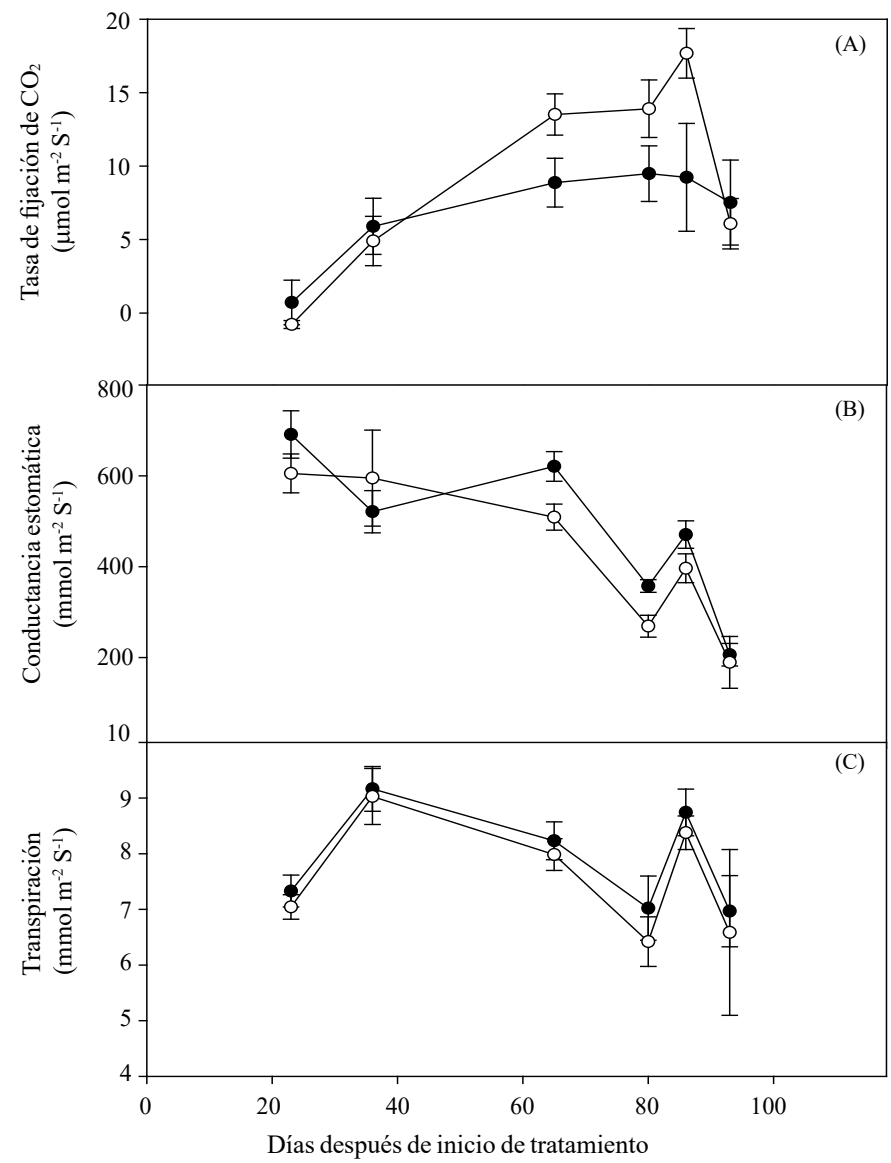

Figura 5. A) tasa de fijación de $\mathrm{CO}_{2}\left(\mu \mathrm{mol} \mathrm{m} \mathrm{m}^{-2} \mathrm{~s}^{-1}\right)$; B) conductancia estomática $\left.\left(\mathrm{mmol} \mathrm{m} \mathrm{m}^{-2} \mathrm{~s}^{-1}\right) ; \mathrm{y} \mathrm{C}\right)$ transpiración $\left(\mathrm{mmol} \mathrm{m}^{-2} \mathrm{~s}^{-1}\right)$ en hojas de jitomatecon raíz dividida y SPR en hidroponía e invernadero. $\bullet=$ testigo; y $\mathrm{o}=\mathrm{SPR}$. Cada punto representa el promedio de seis repeticiones \pm error estándar con observaciones tomadas de 12:00 a 14:00 $\mathrm{h}$.

Figure 5. A) $\mathrm{CO}_{2}$ fixation rate $\left(\mu \mathrm{mol} \mathrm{m} \mathrm{m}^{-2} \mathrm{~s}^{-1}\right)$; B) stomatal conductance $\left(\mathrm{mmol} \mathrm{m}^{-2} \mathrm{~s}^{-1}\right)$; and $\mathrm{C}$ ) transpiration $\left(\mathrm{mmol} \mathrm{m} \mathrm{m}^{-2} \mathrm{~s}^{-1}\right)$ in leaves of tomato plants with split root and PRD in hydroponics and greenhouse. $\bullet=$ control; and $\mathrm{o}=\mathrm{PRD}$. Each point represents the average of six replicates \pm standard error with observations taken from 12:00 to 14:00 h.

Sin embargo, a 93 DDIT se redujo drásticamente hasta 7.5 y $6.07 \mu \mathrm{mol} \mathrm{m}^{-2} \mathrm{~s}^{-1}$, respectivamente. Es notorio que la tasa de fijación de $\mathrm{CO}_{2}$ debido al tratamiento SPR fue 52, 47 y $91 \%$ superior al testigo a 65,80 y 86 DDIT. La conductancia estomática del testigo y SPR se redujo drásticamente desde 691 y 605 hasta 206 y $189 \mathrm{mmol} \mathrm{m}^{-2} \mathrm{~s}^{-1}$, respectivamente (Figura 5 B). A 65, 80 y 86 DDIT, el tratamiento SPR redujo significativamente la conductancia estomática en 18,25 y $16 \%$ respecto al testigo. En cambio, en la transpiración, el been pointed out with respect to what has been observed in this paper. These non-detected differences can be due to the use of different tomato cultivars, species, small changes in environmental conditions prevailing during the studies and phenological stages in which the evaluation was conducted.

\section{Yield}

Yield in terms of fruit fresh matter per plant, showed a $10 \%$ decrease in PRD treatment compared with control, this difference was not statistically significant (Figure 6). Davies et al. (2000) found results similar to those of this paper in relation to fruit fresh matter per plant, when they studied tomato plants with PRD treatment.

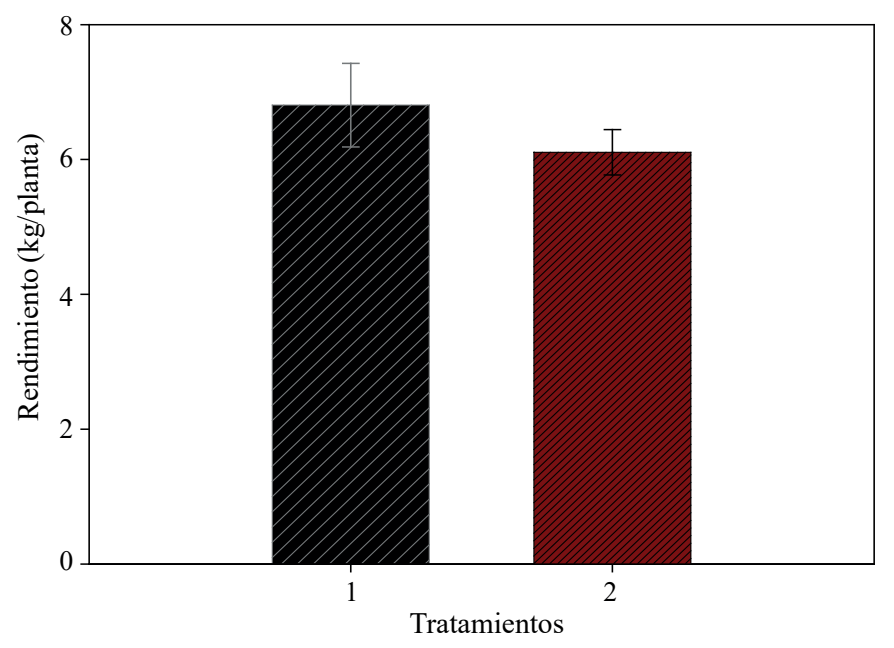

Figura 6. Rendimiento de fruto fresco total de jitomate con diez racimos por planta con raíz dividida y SPR en hidroponía e invernadero. $1=$ testigo; y $2=S P R$. Cada barra representa el promedio de seis repeticiones \pm error estándar.

Figure 6. Total fresh fruit yield of tomato with ten clusters per plant with split root and PRD in hydroponics and greenhouse. $1=$ control; and $2=$ PRD. Each bar represents the average of six replicates \pm standard error.

Fruit quality (firmness, total soluble solids, electrical conductivity and $\mathrm{pH}$ )

According to fruit quality parameters, it was found that in PRD treatment, firmness increased $25 \%$, a $13 \%$ in total soluble solids ( $\left.{ }^{\circ} \mathrm{Bx}\right)$ and $13 \%$ the electrical conductivity (Figure 7A, 7B and 7C respectively). However, $\mathrm{pH}$ was statistically equal between both treatments (Figure 7D). Accumulation of fresh matter of fruit per plant, was not 
tratamiento SPR no tuvo ningún efecto(Figura 5C). Mientras la conductancia estomática y la transpiración disminuyen a través del tiempo, y la tasa de fijación de $\mathrm{CO}_{2}$ tendió a incrementarse. During (2008) señala que la tasa de fijación de $\mathrm{CO}_{2}$. Sin tiene una relación no lineal con la conductancia estomática y esto provocó un aumento en la EUA instantáneo.

En general, esta respuesta fisiológica ha sido atribuida al cierre parcial de los estomas, generado por las señales químicas que provienen de la raíz, sometida a estrés hídrico (During etal., 1996; Davies et al., 2000; Loveys et al., 2000). Sin embargo, en un estudio con un tratamiento similar y en la misma especie, no se encontró efecto significativo en la tasa de fijación de $\mathrm{CO}_{2}$ y la transpiración (Stikic et al., 2003). La respuesta fisiológica general parece ser similar entre los estudios realizados por diversos grupos de investigación cuando se ha evaluado la condición SPR. Sin embargo, se han señalado algunas diferencias notables, respecto a lo observado en el presente estudio. Éstas diferencias no detectadas pueden ser por el uso de diferentes cultivares de jitomate, especies, cambios pequeños en las condiciones ambientales prevalecientes durante los estudios y las etapas fenológicas en que se realizó la evaluación.

\section{Rendimiento}

El rendimiento en términos de materia fresca de fruto por planta, aunque hubo una disminución de $10 \%$ en el tratamiento SPR respectoal testigo, ésta diferencia no fue estadísticamente significativa (Figura 6). Davies et al. (2000) encontraron resultados similares al de este estudio, con relación a la materia fresca de fruto por planta, cuando estudiaron las plantas de jitomate mediante el tratamiento SPR.

\section{Calidad de fruto (firmeza, sólidos solubles totales, conductividad eléctrica y $\mathbf{p H}$ )}

De acuerdo con los parámetros de calidad de fruto se encontró que en el tratamiento de SPR la firmeza incrementó $25 \%$, $13 \%$ los sólidos solubles totales $\left({ }^{\circ} \mathrm{Bx}\right)$ y $13 \%$ la conductividad eléctrica(Figuras 7A, By Crespectivamente). Sin embargo, el pH fueestadísticamente igual entre ambostratamientos (Figura 7 D). La acumulación de la materia fresca de fruto por planta no fue diferente entre tratamientos (Figura 6) y se mantuvo la producción de la materia seca en ambos tratamientos (Figura 3 A). Este comportamiento fisiológico, probablemente se debió a la acción de las señales químicas provenientes de la raízy al suministro de agua suficiente, a través del sistema de raíz dividida. Además, el SPR parece que pudo suministrar different between treatments (Figure 6) and production of dry matter in both treatments was maintained (Figura 3A). This physiological behavior, is probably due to chemical signals action from the root and the provision of enough water through the split root system. In addition, PRD seems able to supply a sufficient amount of water and nutrients to sustain fruit growth (Gowing et al., 2008). Others authors have suggested that even with PRD, there is a decrease in both fruit size and in the fresh fruit per plant rate, but yield expressed as dry matter per plant is not affected, due to increased total soluble solids independent of fruit size (Davies et al. 2000; Zegbe-Dominguez et al., 2003).

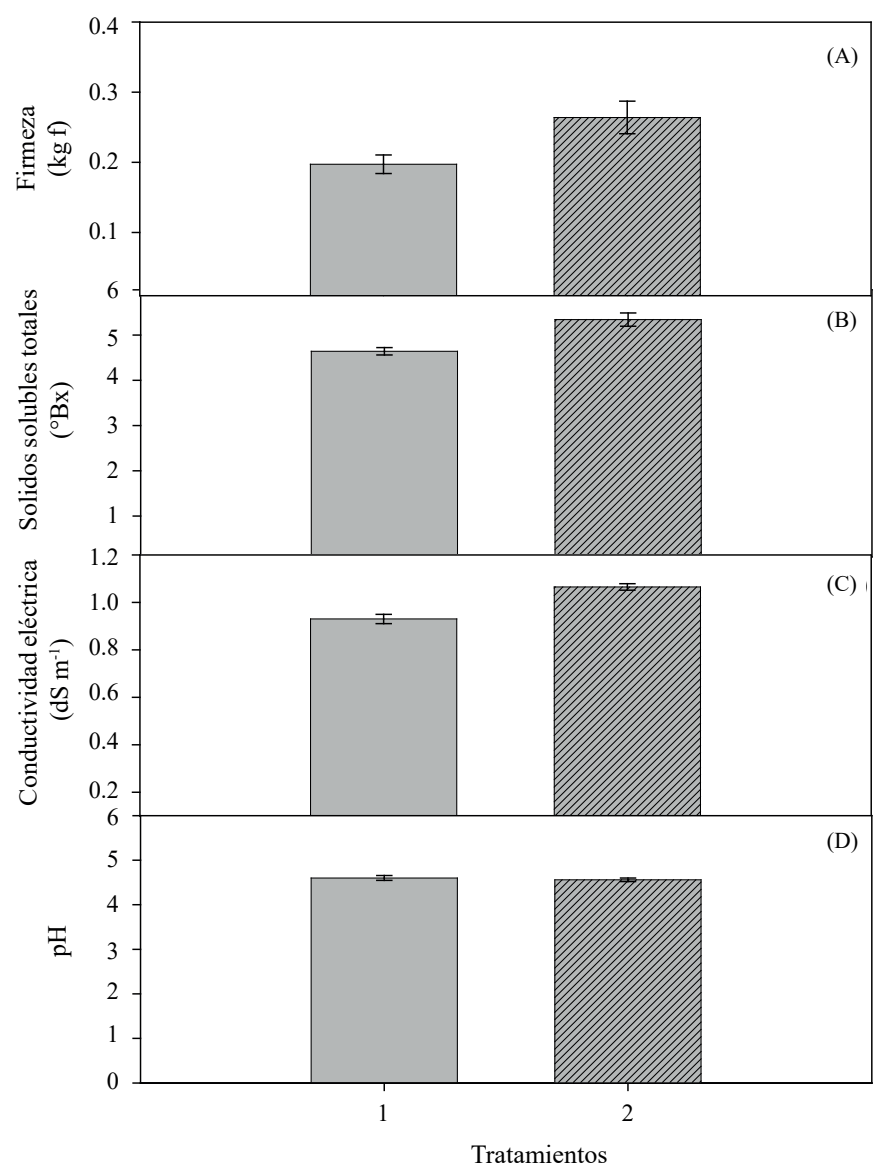

Figura 7. A) firmeza ( $\left(\mathrm{kg}\right.$ f); B) sólidos solubles totales $\left({ }^{\circ} \mathrm{Bx}\right)$; C) conductividad eléctrica $\left.\left(\mathrm{dS} \mathrm{m}^{-1}\right) ; \mathrm{y} \mathrm{D}\right) \mathrm{pH}$ de fruto de jitomate con raíz dividida y SPR en hidroponía e invernadero. $1=$ testigo; $2=$ SPR. Cada barra representa el promedio de cinco repeticiones \pm error estándar.

Figure 7. A) firmness (kg f); B) total soluble solids $\left({ }^{\circ} \mathbf{B x}\right)$; C) electrical conductivity (dS m${ }^{-1}$ ); and $\left.\mathrm{D}\right) \mathrm{pH}$ of tomato fruit with split root and PRD in hydroponics and greenhouse. $1=$ Control; and $2=\mathrm{PRD}$. Each bar represents the average of five replicates \pm standard error. 
la cantidad de agua suficiente y nutrimentos para mantener el crecimiento del fruto (Gowing et al., 2008). Otros autores han señalado, que aún con SPR hay una disminución tanto del tamaño del fruto como del índice de materia fresca de fruto por planta; pero el rendimiento expresado como materia seca por planta no se afecta, debido al incremento de sólidos solubles totales independiente del tamaño de fruto (Davies et al., 2000; Zegbe-Dominguez et al., 2003).

\section{Eficiencia del uso de agua con base en materia fresca y seca de fruto por planta e intercambio de gases}

El volumen evapotranspirado, en todo el ciclo del cultivo fue $18.5 \%$ menor con el tratamiento SPR, respecto al testigo; este porcentaje equivale a ahorrar 42.3 $\mathrm{L} \mathrm{planta}^{-1}$ (Cuadro 1). El ahorro de evapotranspiración fue utilizado para calcular la eficiencia del uso de agua (EUA). Así, cuando la EUA se calculó con base en la materia fresca del fruto por planta, el tratamiento SPR incrementó 10\% la EUA comparado con el testigo; cuando se calculó la EUA con base en la materia seca del fruto por planta, la eficiencia fue aun mayor, pues representó $29 \%$ en relación con el tratamiento testigo (Cuadro 1).

\section{Efficiency in water use based on fresh and dried fruit matter per plant and gas exchange}

Evapotranspirated volume of all the crop cycle was $18.5 \%$ lower with PRD treatment respect to the control, equivalent to saving 42.3 L plant ${ }^{-1}$ (Table 1). Evapotranspiration saving was used to calculate the efficiency in water use (EWU). Thus, when EWU was calculated based on fresh fruit matter perplant, PRD treatment increased a $10 \%$ the EWU compared with control, when EWU was calculated based on the dry fruit matter per plant, the efficiency was even higher, accounting for $29 \%$ compared with the control treatment (Table 1).

Davies et al. (2000), in a paper similar to this one, found that PRD increased EWU in 70 and $93 \%$ based on fresh and dry matter of fruit, respectively.

Instant EWU, equal to the quotient of the $\mathrm{CO}_{2}$ fixation rate divided by transpiration rate, increased 57, 61 and almost $100 \%$ in PRD treatment, at 65, 80 and 86 DAIT (Table 2). Similarly, During et al. (1996) found that EWU increased in $38.5 \%$. Same authors reported that stomatal conductance was reduced by $50 \%$, while $\mathrm{CO}_{2}$ fixation rate was reduced

Cuadro 1. Efecto de dos tratamientos de humedad aprovechable residual en el sustrato, testigo y SPR sobre la eficiencia del uso de agua en el cultivo de jitomate con base en el rendimiento y volumen evapotranspirado total.

Table 1. Effect of two treatments of residual available moisture in substrate, control and PRD on the efficiency of water use in tomato cultivation based on yield and total evapotranspirated volume.

\begin{tabular}{lccc}
\hline \multicolumn{1}{c}{ Variables } & Testigo & SPR & Significancia \\
\hline Materia fresca de fruto por planta $(\mathrm{g})$ & $6806.5 \pm 0.6$ & $6106.8 \pm 0.3$ & $\mathrm{~ns}$ \\
Materia seca de fruto por planta $(\mathrm{g})$ & $345.8 \pm 121.3$ & $363.2 \pm 14.6$ & $\mathrm{~ns}$ \\
Volumen evapotranspirado por planta $\left(\mathrm{L} \mathrm{Planta}^{-1}\right)$ & $229 \pm 38.2$ & $186.7 \pm 55.3$ & $*$ \\
EUAde materia fresca de fruto por planta & 0.02972 & 0.0327 & - \\
EUAde materia seca de fruto por planta & 0.00151 & 0.00195 & - \\
\hline
\end{tabular}

$\overline{\mathrm{SPR}}=$ secado parcial de la raíz; $\mathrm{EUA}=$ eficiencia del uso de agua; $\mathrm{ns}=$ no significativo $\mathrm{y} *$ significativo $\operatorname{con} p \leq 0.05$, de acuerdo a la prueba de " $\mathrm{t}$ ".

Davies et al.(2000), en un trabajo similar al presente estudio, encontraron que el SPR incrementó la EUAen 70 y $93 \%$ con base en la materia fresca y seca de fruto, respectivamente.

LaEUA instantánea, igual al cociente de la tasa de fijación de $\mathrm{CO}_{2}$ entre la tasa de transpiración se incrementó 57,61 y casi $100 \%$ en el tratamiento SPR, a 65,80 y 86 DDIT (Cuadro 2). Similarmente, During et al.(1996) encontraron que la EUA incrementó $38.5 \%$. Los mismos autores señalaron que la conductancia estomática se redujo $50 \%$ mientras que la tasa de fijación de $\mathrm{CO}_{2}$ se redujo sólo $30 \%$; este comportamiento no lineal entre las dos variables fisiológicas, condujo al incremento significativo de la EUA(During, 1993). by only $30 \%$, this nonlinear behavior between the two physiological variables, led to a significant increase in the EWU (During, 1993).

Discrepancy between results can be attributed to several factors. Thus, Steiner's nutrient solution (1984), used in this experiment, has a $\mathrm{pH}$ that is alkaline to physiological processes, because the nitrogen source of this solution is based on nitrates. With the increase of the extracellular $\mathrm{pH}$, may have increased the sensitivity of stomata to regulate stomatal conductance and resulting in the significant EWU, in this regard, there is some evidence in the literature. 
Cuadro 2. Efecto de dos tratamientos de humedad aprovechable residual en el sustrato, testigo y SPR sobre la tasa de fijación de $\mathrm{CO}_{2}$, transpiración y la eficiencia en el uso del agua en la hoja de jitomate completamente expandida, en tres fechas DDIT.

Table 2. Effect of two treatments of residual available moisture in substrate, control and PRD on the $\mathrm{CO}_{2}$ fixation rate, transpiration and efficiency in water use in fully expanded tomato leaf, on three dates DAIT.

\begin{tabular}{|c|c|c|c|c|c|c|}
\hline \multirow{2}{*}{ Variables } & \multicolumn{2}{|c|}{65 días } & \multicolumn{2}{|c|}{80 días } & \multicolumn{2}{|c|}{86 días } \\
\hline & Testigo & SPR & Testigo & SPR & Testigo & SPR \\
\hline Tasa de fijación de $\mathrm{CO}_{2}\left(\mu \mathrm{mol} \mathrm{m}^{-2} \mathrm{~s}^{-1}\right)$ & $8.86 \pm 1.66$ & $13.51 \pm 1.4^{*}$ & $9.48 \pm 1.89$ & $13.90 \pm 1.95^{*}$ & $9.23 \pm 3.67$ & $17.67 \pm 1.68^{*}$ \\
\hline Transpiración $\left(\mathrm{mmol} \mathrm{m}^{-2} \mathrm{~s}^{-1}\right)$ & $8.23 \pm 0.34$ & $7.98 \pm 0.28 \mathrm{~ns}$ & $7.02 \pm 0.57$ & $6.41 \pm 0.44 \mathrm{~ns}$ & $8.74 \pm 0.41$ & $8.37 \pm 0.3 \mathrm{~ns}$ \\
\hline EUA(A/T) & 0.001076 & 0.001692 & 0.00135 & 0.002168 & 0.001056 & 0.00211 \\
\hline
\end{tabular}
acuerdo a la prueba de " $\mathrm{t}$ ".

La discrepancia entre los resultados puede ser atribuida a diferentes factores.Así, la soluciónnutritiva de Steiner(1984), utilizada en este experimento, tiene un $\mathrm{pH}$ que para los procesos fisiológicos es alcalino, debido que la fuente de nitrógeno de esta solución es a base de nitratos. Con el incremento del $\mathrm{pH}$ del medio extracelular, pudo haber aumentado la sensibilidad de los estomas para regular la conductancia estomática y por ende aumentardeuna manera significativa laEUA; al respecto, se han reportado algunas evidencias en la literatura.

Los efectos de la fuente de $\mathrm{N}$ en los cambios y balance de $\mathrm{pH}$ del apoplasto y el efecto que tiene éste en la sensibilidad de los estomas, fueron documentados por Schurr et al. (2009); Kosegarten etal.(1999); Muhlingy Lauchli(2001).Esosautores encontraron que varias concentraciones de $\mathrm{NO}_{3}{ }^{-}$en la savia del xilema de plantas de girasol, en condiciones de estrés hídrico, incrementan el $\mathrm{pH}$; de esa manera se regula la sensibilidad del estoma por la acción del ABA. Alternativamente, Raven y Smith, (1976) reportaron que es posible que el ABAy el ion $\mathrm{NO}_{3}{ }^{-}$interactúen para afectar el funcionamiento del estoma, a través de cambios en el pH de la hoja.

\section{CONCLUSIONES}

El tratamiento SPR estimuló el sistema de señales químicas entre la raíz y el vástago.

El SPR propició el incremento del intercambio de gases, la calidad de fruto y la eficiencia en el uso del agua, sin afectar el rendimiento y las relaciones hídricas.

Esta técnica de riego ayuda a utilizar menos agua para la producción de jitomate y por lo tanto incrementar substancialmente la eficiencia del uso de agua.
The effects of $\mathrm{N}$ source on $\mathrm{pH}$ changes and balance of the apoplast and the effect it has on the sensitivity of stomata, were documented by Schurr et al. (2009); Kosegarten et al. (1999); Muhling and Lauchli (2001). These authors found that various concentrations of $\mathrm{NO}_{3}^{-}$in the xylem sap of sunflower plants under water stress conditions, increase the $\mathrm{pH}$, thereby is regulated the stoma sensitivity by the ABA action. Alternatively, Raven and Smith (1976), reported that is possible that $\mathrm{ABA}$ and $\mathrm{NO}_{3}{ }^{-}$ion interact to affect the stoma operation, through changes in the leaf's $\mathrm{pH}$.

\section{CONCLUSIONS}

PRD treatment, stimulated the chemical signaling system between root and stem.

PRDled to increased gas exchange, fruit quality and efficiency in water use without affecting the yield and water relations.

This irrigation technique helps to use less water for tomatoes production and therefore substantially increase the efficiency of water use.

End of the English version

\section{LITERATURA CITADA}

Association of Official Agricultural Chemist (AOAC). 1990. Official methods of analysis of AOAC international. Fruits and fruit products. $829-830 \mathrm{pp}$. 
Bates, L. M. and Hall,A. E. 1981. Stomatal closure with soil water depletion not associated with changes in bulk leaf water status. Oecología. 50:63-65.

Davies, W. J.; Bacon, M. A.; Thompson, D. S.; Sobeih, W. and Rodríguez, G. L. 2000. Regulation of leaf and fruit growth in plants growing in drying soil: exploitation of the plants chemical signalling system and hydraulic architecture to increase the efficiency of water use in agriculture. J. Exp. Bot. 51(350):1617-1626.

Dorji, K.; Behboudian, H. M. and Zegbe-Dominguez, A. J. 2005. Water relations, growth, yield, and fruit quality of hot pepper under deficit irrigation and partial rootzone drying. Sci. Hortic. 104:137-149.

During, H. 2008. Gas exchange of grapevine leaves as affected by soil factors. Proc. $4^{\text {th }}$ Int. Symp. Grapevine Physiol. Turin 1992. 295-298 pp.

During, H.; Loveys, B. R. and Dry, P. R. 1996. Root signals affect water use efficiency and shoot growth. In: Proc. Workshop Strategies to Optimize Wine Grape Quality. Eds. Poini, S.; Peterlunger, E.; lacono F.; Intrieri C. (eds.). Acta Hortic. 427:1-13.

Gowing, D. J. G.; Davies, W. J. and Jones, H. G. 2008. A positive root-sourced signal as an indicator of soil drying in apple, malus domestica Borkh. J. Exp. Bot. 41(233):1535-1540.

Kosegarten, H. U.; Hoffmann, B. and Mengel, K. 1999. Apoplastic $\mathrm{pH}$ and $\mathrm{Fe}^{3+}$ reduction in intact sunflower leaves. Plant Physiol. 121:1069-1079.

Kramer, P. J. 1988. Changing concepts regarding plant water relations. Plant Cell Environ. 11:565-568.

Loveys, B. R.; Dry, P. R.; Stoll, M. and Mc Carthy, M. G. 2000. Using plant physiology to improve the water use efficiency of horticultural crops. Acta Hortic. 537:187-197.
Muhling, K. H. and Lauchli, A. 2001. Influence of chemical form and concentration of nitrogen on apoplastic $\mathrm{pH}$ of leaves. J. Plant Nutr. 24:399-411.

Raven, J. A. and Smith, F. A. 1976. Nitrogen assimilation and transport in vascular land plants in relation to intracellularpHregulation. New Phytol. 76:415-431.

Schurr, U.; Gollan, T. and Schulze, E. D. 2009. Stomatal response to drying soil in relation to changes in the xylem sap composition of Helianthus annus 2. Stomatal sensitivity to abscisic acid imported from the xylem sap. Plant. Cell Environ. 15:561-567.

Sigmaplot of Jandel Scientic. 2001. User's guide. Flying Raichu von. Version 7.1 SPSS Science Inc. 435 p.

Steiner, A. A. 1984. The universal solution. I.S.O.S.C. Proceedings $6^{\text {th }}$ International Congress on Soilles Culture. 633-649 pp.

Stikic, R.; Popovic, S.; Srdic, M.; Savic, D.; Javanovic, Z.; Prokic, L. J. and Zdravkovic, J. 2003. Partial root drying (PRD): a new technique for growing plants that saves water and improves the quality of fruit. J. Plant Physiol. Special Issue. 164-171 pp.

Stoll, M.; Jones, H. G. and Infante, J. M. 2002. Leaf gas exchanges and growth in red raspberries is reduced when part of the root system is dried. Acta Hortic. 585:671-676.

Zegbe-Dominguez, A. J.; Behboudian, H. M.; Lang, A. and Clothier, E. B. 2003. Deficit irrigation and partial rootzone drying maintain fruit dry mass and enhance fruit quality in 'Petopride' processing tomato (Lycopersicon esculentum, Mill.). Sci. Hortic. 98:505-510.

Zhang, J. H. and Davies, W. J. 2009. Changes in the concentration of ABA in the xylem sap as a function of changing soil water status can account for changes in leaf conductance and growth. Plant Cell Environ. 13:277-285. 